Herman V. Marchenko

Shchukin Theater Institute e-mail: marchenko2008@yandex.ru

Moscow, Russia

ORCID 0000-0002-6226-0962

DOI: 10.36340/2071-6818-2021-17-3-50-64

\section{THE VAKHTANGOV SCHOOL: CREATION OF TEACHING METHODS}

Summary: The article presents information about the faithful disciple of Evgeny Vakhtangov, Boris Zakhava. For 50 years, Boris Zakhava continuously led the Shchukin Theater Institute. He was, perhaps, the only one of Vakhtangov's students who having come to the Studio from the first days of its foundation, remained faithful to the theatrical principles of Evgeny Vakhtangov. Also, the article examines the period of creation of Zakhava's method of teaching acting at the Shchukin Theater Institute. A significant role in the formation of Zakhava as a theorist and teacher was played by his teacher Evgeny Vakhtangov, a student of Stanislavski. Vakhtangov mastered the method of Stanislavski's work with an actor and became the head of the Mansurov Studio, continued to search for new theatrical techniques, influencing the formation of Zakhava's creative personality. In his practice, Vakhtangov moved away from the realism of the early Moscow Art Theater and created his direction, which he called fantastic realism. Thanks to his pedagogical talent, many wonderful actors appeared, who were able to achieve the independence of the Studio and organise not only the theatre named af ter their teacher but also to preserve the theatre school based on the principles of the work of Evg-

On October 23, 1914, Vakhtangov gave the first ecture on Stanislavski's system to the students of the Moscow Commercial Institute. This is how the Mansurov studio and later the school, now called the Shchukin Theater Institute, appeared. Zakhava was among the first students. He later recalled this meeting: "I am a student of Stanislavski, - said Vakhtangov, - I see the meaning of my work with riously engage in directing, attended Stanislavski's rehearsals and worked as a second director with V.Nemirovich-Danchenko. Konstantin Stanislavsk noticed the perseverance and interest of an actor who was beginning his professional path. After a while, he invited him to engage in active teaching activities with a group of young actors. Stanislavski's system did not yet exist in published form; thus, Vakhtangov had to go not from theory to practice but on the contrary, to practically prove the creative consistency of new methods of teaching acting. Soon, owing to his successful work according to Stanislavski's method, the management of the theatre decided to create a studio at the Moscow Art Theater (later called the First Studio) under the leadership of L.Sulerzhitsky, where Vakhtangov would stage Das Friedensfest (1913) by G.Hauptmann, The Flood (1915) by G.Berger, Rosmersholm (1918) by H.Ibsen, Eric XIV (1921) by A.Strindberg, and would also play several prominent roles: Tackleton (1914) in the fairy tale The Cricket on the Hearth by Dickens, Fraser (1915) in the play The Flood by Berger.

Evgeny Vakhtangov was one of the most loyal supporters of Stanislavski's method, the purpose of which is for the actor to convey the "life of the human spirit of the role" through natural existence in the given circumstances of a play. The artist's mastery of a natural feeling, which allows them to act and think on stage in almost the same way as in real life, is the most important task of the system. The main difference lies in the fact that a primary emotional system is triggered in a person's life which is a response to factors influencing the person from the outside. It is a kind of self-preservation instinct. At the moment of stage existence, an actor manifests a secondary emotional system, artificially, through technical elements, recreated by the actor in specific given circumstances: "On this basis, he (Stanislavski) developed several psychotechnical techniques that cause the inner world of a person to be creative" 2 .

Zakhava was destined to continue Vakhtangov's work, developing the methodology of theatrical pedagogy and preserving the heritage of the great teacher. After completing a three-year training program at the Mansurov studio, Boris Zakhava showed an interest in directing and pedagogy. In 1918, Evgeny Vakhtangov created directing and teaching classes so that his actors could themselves 2. Shikhmatov, L.M., Lvova, V... Scenic Studies. Moscow: VTsKhT,
2006. P.9

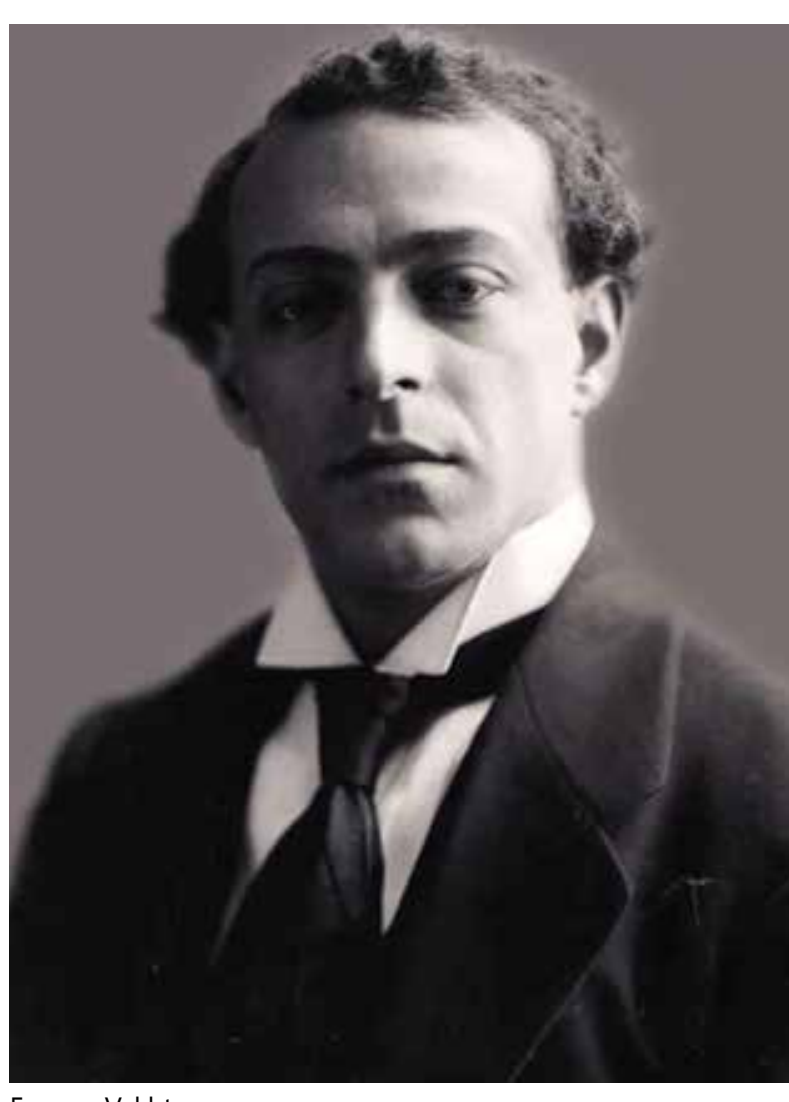

Evgeny Vakhtangov

be engaged in staging performances and teaching This period of the school's existence is also interesting because young professionals, who had recently been students, became stronger professionally. Therefore, Vakhtangov refused to invite teachers from outside; now, he could rely entirely on the knowledge of his artists. Moreover, the practised method of educating and training future actors required a single direction based on the principles of the Vakhtangov school, which only the students of Evgeny Vakhtangov could fully master. The director's class included K.Kotlubay, Y.Zavadsky and B. Zakhava. Boris Zakhava, on the recommendation of his teacher, conducted teaching activities in other collectives. Some students of these theatrical com munities would later join the Vakhtangov studio.

Evgeny Vakhtangov paid much attention to the aesthetic, moral education of his students. A set of rules and laws, the implementation of which was mandatory for all members of the theatrical organisation, was adopted: "The students pay so much attention to the moral code of the studio that it begin to become an end in itself for them"3. For him, the process of int it helped to identify the artist's worldview, as well as 3. Khersonsky, K.N.: Vakhtangov. The Life of Wonderful People.
Moscow:: Molodogvardia, 1940. P.137 
the ability to sensitively feel modernity and express it through a personal attitude in his work. Vakhtangov's pedagogical talent, first of all, consisted of the fact that he had an individual approach to each student. He could easily captivate the student with a creative atmosphere at rehearsals and awaken the desire for independent inner work on the role. The school created conditions under which future actors could and wanted to engage in achieving professionalism. Evgeny Vakhtangov believed that with this approach, the beginners who comprehend the basics of mastery start to be aware of the need for their development. Students feel that they can try, make mistakes, engage in the process of learning about their individuality, feel inner freedom, which makes it possible for professional growth.

The drama teaching methodology had been created and corrected for more than a decade. Zakhava played a central role in this. Gradually, from 1931 to 1941 , the training system was formed. In 1925 Zakhava introduced the principle of working with students into the school curriculum at the Evgeny Vakhtangov Theater. In a letter to O.Glazunov, he spoke of the need to create a new approach to the education of students: "It is necessary to put, so to speak, each student under the crossfire of various pedagogical influences, teaching individualities" 4 From that time on, active work to create the basic principles of teaching began. The creative process with the maximum number of teachers is important from the point of view of expanding the student's potential. On the other hand, if the "chemical" (creative) process did not happen with one teacher, then the work process may be more success ful with another one. In the future, Zakhava's idea would help graduates to interact with different directors, make the actors more flexible in their approach to the profession

Zakhava was one of those directors who attached great importance to the so-called special disciplines. For example, if a student missed an extra class, they an incredibly harsh punishment for the wtu 1936 , the technical school with a 3-year education was reorganised into a 4-year school. This reform yielded positive results due to the introduction of an additional series of art history subjects, which raised the general cultural level of students: "Mas-

4. Vakhtangov School. Chronicle. Part 1: From the personal arChive of $81-82$ tery is what our curriculum consists of. Mastery is the whole amount of knowledge and skills that a studen of our school must acquire" ${ }^{5}$. Teachers were looking or the right approach to st the need for overall development of course, in the beginning, they faced misunderstandings from the students. However, over time, students had felt the benefits of this approach to teaching.

In the 1930s, a new acting skills program was developed in detail. All definitions and formulations were clarified, and some sections were finalised and expanded: "Methodical experiments began to be carried out. What had been found was stated in the program. In a word, serious scientific and methodological work was going on" ${ }^{\prime \prime}$. In about 1935 , Zakhava decided to introduce and test some of the fundamentals of the methodology, and by 1939, he had introduced a new educational system for teaching acting skills for students. This step was fundamental in the process of further development of the school as one of the best educational institutions in the country. Of course, the introduced program primarily influenced the training of graduates and their acting arsenal. School teachers and directors of the Vakhtangov Theater focused on the difference between school graduates before the introduction of the new methodology and after it: "Starting from about 1938, our graduates with whom it is easy to work began to enter the troupe of the Vakhtang ov Theatre. They know how to work independent$y$, they know how to take on a role" ${ }^{\prime 7}$. According to the recollections of teachers, the graduates of the school were, of course, talented artists before the introduction of the new training system; however, in their profession, they often had a rather difficult time interacting with the director's approach to interpreting a particular work of art, especially if they were asked to work on their own role material. Until the mid-30s of the $20^{\text {th }}$ century, the school under the leadership of Zakhava, was within the walls of the Vakhtangov Theater, which allowed students, being in their first year, to take part in profession-

5. "On the Formation of a Student's Personality in a Theatrical . Article. 1971-1974, Russian State Archives of LitP.34. Zakhava, B.E: Manuscript. The Shchukin Theater School at the Vakhtangov Theater. Shchukin Theater Institute. 1951. P.22 A transcript of the lesson of the creative laboratory of foll theatre directors. Conversation with B.Zakhava (on the education of actors), October 8, 1961, on 67 sheets. The Central
State Archive of Literature and Art of the USSR. F No 970 inventory No. 21 , storage No. 3193. P.35. al productions. However, with the introduction of a four-year education in 1936 and a change in teaching methods, the school, having separated from the theatre, acquired a new building by 1937 . Thus, it became possible to introduce an important practical tool into the education system - the Educational Theater, which was put into operation in paralle with the school found at Bolshoy Nikolopeskovsky lane, 12a. From 1939, the emergence of the new premises and thus, additional opportunities for creative development allowed the Shchukin school named after the best actor of the Vakhtangov Theatre, who passed away in the same year, to stage graduation performances permanently completing the learning process. Students had the opportunity to get acquainted with the theatre's incredibly interesting and complex structure since freshmen were engaged in servicing graduation performances, thereby gaining invaluable experience with the technical structure of the theatre, learning certain laws of behaviour and relationships with workers, costume designers, artists. In the future, the knowledge they gained helped to painlessly move to the collective of any professional theatre since the graduates, internally, were already ready for the specifics of relationships in such a complex organism. Boris Zakhava considered this practice to be the key to successfully mastering the theatrical profession: "Without the practice of student performances, without the presence of a constantly functioning educational theatre, no school can fulfil this educational task" ${ }^{18}$. After the end of World War II in 1945 the school was given the rights of a higher educational institution, in connection with which it became possible to send graduates to work in many theatres of the country.

In 1951, the teachers of the Shchukin Theater Institute, headed by Zakhava, met with a commission from GITIS under the leadership of the head of the Acting Department, Professor I.Raevsky. Consultations on the methods of teaching acting skills were held. Particular attention was paid to teaching students in the second year: professional skills, character observations and exercises. Representatives from GITIS proposed to study the essence of stage transformation based on the ideological meaning of a literary work, and not to invent given circumstances, as had been done before this meeting: "They were right in this (speaking of the assessment from

8. Zakhava, B.E: Manuscript. The Shchukin Theater School at the
Vakhtangov Theater. Shchukin Theater Institute. 1951. Pp.8-9 the commission from GITIS). Therefore, we restruc tured our work; we introduced a significant reform We stopped naming these exercises character element exercises and began to call them exercises for character thanks to a task from one or another literary material" 9 . This meeting and the outside view of the GITIS teaching staff had a significant impac on changing the section of the curriculum for the first semester of the second year. As a result, this section took its final and complete form.

Returning to the specific structure of the methodological foundations of the student training program at the Shchukin Theater Institute, we see that of course, taking into account the change of time this teaching methodology has undergone changes in some aspects. However, the essence laid down by Vakhtangov, formulated, as well as supplemented and consistently structured by Zakhava, remain the basis and does not change.

The first year of study was dedicated to the study of the Stanislavsky system sections, based on the principle of life's truth, the doctrine of a super-task action, as the basis of acting technique, organicity and the creative transformation of an actor into character. The main task of Stanislavski's system is to identify the artist's organic well-being and the natural process of reincarnation. During the entire first year, students learn theoretically and consolidate through practice the stage alphabet, that is, the fundamental laws of the internal technique of acting. There is a process of education of certain abilities and skills in students, which subsequently help the student to approach the correct stage well-being the specific and truthful conditions of the creative act. Accordingly, in the first year, the main goal is to reveal a "sense of truth" in students, that is, organic existence on the stage. For the entire first year they exist within the "me in the given circumstances" framework. Paradoxical as it may sound, but a the first stage of mastering the elements of stage existence "we forget everything: how we walk in life and how we sit, eat, drink, sleep, talk, look"10, as Boris Zakhava said. This stage is crucial for the future actor since the creation of the character takes place through the connection of a personal sensory series, comparable to the emotional nature of the charac ter played by the actor in the play. However, this is

9. Zakhava, B.E: Manuscript. The Shchukin Theater School at the 10. Shikhmatov, L.M., Lvova, V.K.: Scenic Studies. Moscow: VTsKh 2006. P.24 
not yet the stage image itself; it is only the basis on which the role is built. At the first stage of relationships with students, the sequence of practical study of the elements of correct stage well-being, which subsequently lead to the organic origin of action in the stage existence of students, is essential. There are several exercises that students perform: exercises on attention, physical freedom, simple physical actions, fantasy and imagination, a change in attitude to an object, a place of action, as well as exercises for physical well-being and for the memory of physical actions, exercises for evaluating a fact, an event, a change in attitude towards a partner, exercises on stage communication and sketches for communication in conditions of organic silence, stage relations within the framework of a magical "if only". A necessary clarification is that all exercises are performed without words. The simplest plot sketches in conditions of justified silence (without words) are the next step in the first year's program. The training of this element of learning leads students to the organic birth of the word. Of course, in these sketches, a small amount of justified text is allowed, expressing the student's eventual change or emotional identification at a particular moment in the turn of the plotline.

As a rule, students study a section called the memory of physical actions in parallel with sketche for justified silence. With the help of these exercises, the previously acquired skills are tested: attention internal muscular freedom, stage faith, physical sensations. In the future, this section, of course, helps students expend exactly as much physical effort as necessary for the correct interaction with real objects in the conditions of stage action. The process of working on exercises for the memory of physical actions is quite complicated and requires maximum involvement of the student, who needs to achieve the highest performance.

In the second semester of the first year of study students are trained in logical and expedient action on stage in given circumstances in sketches with mprovised text. During participation in such exercises, students learn to understand the essence of physical and verbal actions and also understand the indivisibility of the physical and the mental in the nature of acting. At the end of the year, students hand over sketches with improvised text, the storyline of which allows students to remain themselves and act in the conditions of "me in the given circumstances". Throughout the entire first course, there is a strict sequence of studying the elements of the Stanislavski system.

Vakhtangov liked to call the second year (the third year under the conditions of a three-year training system) "our year" ${ }^{11}$. The program of the first semester of this year is fundamentally different from other theatre schools. Finding the way to create character is a separate section of the training. It includes observation, professional skill, and sketches for the character. Zakhava often repeated the phrase that became a landmark for the institute: "To become different, while remaining oneself" ${ }^{\prime 2}$. It is this principle of organic reincarnation that is the basis of this semester. Observations are the first serious step towards stage presence. This semester, students are faced with the need to observe the life around them and remember interesting people with un usual character traits that they meet; students collect the noticed details in their behaviour in their acting "piggy bank". Pupils observe not only people but also animals and even objects, endowing them with a human character. A successful observation is the one the "grain" of which the studen was able to express. That is the essence of another person, appropriated by the actor, which for a while became their own and dear to them. The presentation includes observations of humans, animals, fantasy exercises - observation of objects, as well as musical observations of famous pop artists. In the same semester, students master a professional skil (physical activity of a specific profession). In no case should a student master this or that profession; it is essential to grasp its external characteristics. Since for the first time, the student is faced with the fact that stage time is significantly different from life, then the purpose of this task is a point and specific imitation of the professional process, which consists of free and specific movements. Throughout the entire third semester in the second year, students are consistently engaged in the search for the essence of the image, the actor's reincarnation. A the end of the semester, students play sketches for the image with an impromptu text. Zakhava stated: "The leap from sketches made by oneself, 'me in the given circumstances', to work on the image, which should be created based on the author's text is too quick" ${ }^{\prime 13}$. Therefore, it was decided to invite 11. Zakhava, B.E: Manuscript. The Shchukin Theater School at the 2. Ibid, p.30

13. Zakhava, B.E: Manuscript The Shchukin Theater School at the Zakhava, B.E: Manuscript. The Shchukin Theater School at the
Vakhtangov Theater. Shchukin Theater Institute. 1951. Pp.40-41 the student to comprehend the process of creating an image not on dramatic material but prosaic material since the author describes in detail the life of the characters, their characters, and, therefore, it is much easier for the student to penetrate into the inner world of the heroes. When distributing roles, teachers, as a rule, offer their students several options for stage existence: "Situations that are in the work, which are mentioned and which are not in the work, but they could be there" ${ }^{14}$. Having chosen a specific situation in which the hero finds himself or herself, the student, trying on the "image", begins to act on behalf of the character through the free improvisation of the text in the given circumstances. This section of the Vakhtangov School is essential, as it sums up a certain line of the first three semesters. During this time, students go from comprehending the psychological truth of the existence of "me in the given circumstances" to the search for the essence of the image. The principle "from simple to complex" 15 , introduced by Boris Zakhava, is preserved. In these three semesters, the foundations of the Vakhtangov Theatre School are laid. All sections come out of one another and absorb the previous one. Thus, there is a continuous sequential learning chain. The goal of the Shchukin Theater Schoo is to help actors develop their own techniques for creating a stage image. At the end of the second year of study, students play their first short excerpts, staged by teachers, 5-7 minutes long on dramatic material. Zakhava asserted: "Easy, understandable to students, close to their perception, modern material is used"16. This semester is associated with the study of the process of creating an image based on literary material. It is best to select the material in which the author of the work did not impose special requirements on the form, and the given circumstances are clear or well known to the students. An essential pedagogical task is the exact distribution of roles between students, so at this stage, it is important to select material that is close to the individuality of each student. In the process of creating an image, students try to appropriate the relationship of another person (character). A test of how much the main sections of the theatre school have been mastered and familiarity with the meth-

14. Burov, A.G., Lyubimtsev, P.E.: Actor's Mastery. Moscow: Shchukin Theater Institute, 2005. P.22

15. Zakhava, B.E: Manuscript. The Shchukin Theater School at the

16. Zakhava B E. Manuscript The Shchukin Theater School at the

Vakhtangov Theater. Shchukin Theater Institute. 1951. P30 od of working on a role in a specific dramatic com position are the main tasks.

In the third year of study, students play multipart excerpts from the works of world drama. In the first semester, the stage time for students' increases to $15-20$ minutes, and already in the second semester of the third year, a whole act is proposed as a claim for a performance.

In the fourth year, students, during a whole year of study, perform diploma performances. The artistic director compiles the course repertoire, dis tributing roles among students so that, in practice, everyone is engaged in at least two productions. Zakhava attached great importance to the repertoire of do this from the very beginning.

The demonstration of students' independent work at the institute is another distinctive feature of the Vakhtangov School. Students, starting from the second semester of the first year, prepare their performances. They choose the material that is close to them, work with it without outside help, and then perform excerpts for the teachers of the department. The work of first-year students should not take more than 10-13 minutes, and it is undesirable to take the masterpieces of world drama immediately. In the second year, the material is already chosen more complex, and in the third year of study, students are offered the opportunity to hold two such performances. It should also be noted that in the third year, there are also performance evenings, which an outside viewer may attend. These programs are usually composed of the best teaching passages from the fourth semester and the examination works from the fifth semester. Independent performances and performance evenings are included in the methodology of professional training and it was not by chance that they were introduced into the educational process by Zakhava. Vakhtan gov, studying with the students, introduced performances of student works and open performance evenings into the compulsory program. Boris Zakhava perfectly understood the benefits of such a pedagogical approach in working with students since such tests of creativity help the student to open up unexpectedly, demonstrate their inner world, life views to teachers since the stage is a kind of mirror where you can clearly see the individual characteristics of the student.

Boris Zakhava was one of the few who came to the Studio in the year of its foundation and re- 
mained devoted to it for life. He made a considerable contribution to the formation of the Shchukin Theater Institute and the preservation of the Evgeny Vakhtangov Theater. For more than 50 years, he was the rector of the institute. During this period the program of education and training in acting was finalised. A huge number of the greatest actors were released, and the Directing Department was found ed. More than a decade would pass and Zakhava would determine for himself what an ideal graduate of the Shchukin Theater School should be: "Once I

thought about the question of what I would like to see each student of our Shchukin School. I wanted to construct in my mind, so to speak, an ideal model of a graduate of a theatre university. I counted about six main facets of such a model: talent and brilliant technique, the ability to think deeply and meaningfully, penetrating into the very essence of life, high moral qualities, social activity"17. 17. Zakhava, B.E: On the Training at the Shchukin Theatre School
F. No. 034, inventory No. 1, storage 188, the early 1970 s. P.12

REFERENCES

1. Burov, A.G., Lyubimtsev, P.E.: Actor's Mastery. Moscow: Shchukin Theater Institute, 2005. P.36.

2. Vakhtangov School. Chronicle. Part 1: From the personal archive of B.Zakhava. Moscow: Shchukin Theater Institute, 2004. P.376.

3. Zakhava, B.E. 1951. Manuscript. The Shchukin Theate School at the Vakhtangov Theater. Shchukin Theate Institute, p.64.

4. Zakhava, B.E. 1961, "Holiday of the Human Spirit", Oc tober, no. 9, p.16.

5akhava, B.E. 1975. "Education of Directors at the Shchukin School", Theater, no. 7-8, p.115.

6. Zakhava, B.E. 1982. Memories. Performances and Roles. Articles. Moscow, p.402.

7. Zakhava, B.E. On the Training at the Shchukin Theatre School. F. No. 034, inventory No. 1, storage 188, the early 1970 s, p.12.

8. Khersonsky, K.N. 1940. Vakhtangov. The Life of Wonderful People. Moscow: Molodogvardia, p.318.

9. Shikhmatov, L.M., Lvova, V.K. 2006. Scenic Studies. Moscow: VTsKhT, p.240.

10. "On the Formation of a Student's Personality in a The atrical University". Article. 1971-1974, Russian State Ar- chives of Literature and Art. F. No. 3034, inventory No. 1, storage No. 152. p.34

1. A transcript of the lesson of the creative laboratory of folk theatre directors. Conversation with B.Zakhav (on the education of actors), October 8, 1961, on 67 sheets. The Central State Archive of Literature and Art of the USSR. F. No. 970, inventory No. 21, storage No. 3193. p.35.

12. Wollen, W. 2016. "The Active Text: Unlocking Plays Through Physical Theatre", Stanislavski Studies, no 4 pp. 83. DOI: 10.1080/20567790.2016.1155370 (in English)

3. Skinner, A. 2015. "An Introduction to the Russian The ater Research Network", Stanislavski Studies, no.3, pp. 32. DOI: $10.1080 / 20567790.11428609$ (in English)

14. Shulgat, A. 2016. "Vsevolod Meyerhold: Actor as the Texture of Theatre", Stanislavski Studies, no. 4, pp. 179. DOI: 10.1080/20567790.2016.1241553 (in Russian)

15. Aquillina, S. 2020. "Teaching Stanislavski: Periodization and the Formation of Theatre Canons", Stanislavski Stud(in English) ies, no. 2, pp. 53. DOI: 10.1080/20567790.2020.1718862
Герман Владимирович Марченко Театральный института имени Б.В. Щукина

e-mail: marchenko2008@yandex.ru

Москва, России

ORCID 0000-0002-6226-0962

DOI: 10.36340/2071-6818-2021-17-3-50-64

\section{ВАХТАНГОВСКАЯ ШКОЛА: СОЗДАНИЕ МЕТОДИКИ ОБУЧЕНИЯ}

Аннотачия: В статье представлена информация о верном ученике Евгения Богратионович Вахтангова - Б.Е. Захаве. Борис Евгеньевич в течение 50 лет бессменно руководил Театральным институтом имени Б. Щукина. Он оказался, пожалуй, единственным из учеников Вахтангова, кто, придя в Студию с первых дней её основания, остался верен театральным принципам Евгения Богратионовича. Также в статье исследуется период создания Захавой методики преподавания актерского мастерства в Театральном институте имени Б. Щукина. Большую роль в становлении Захавы как теоретика и педагога сыграл его учи тель - Евгений Богратионович Вахтангов - ученик К.С. Станиславского. Вахтангов освоил методику работы Станиславского с актером и, став руководителем Мансуровской студии, продолжил заниматься поиском новых театральных приёмов оказав влияние на формирование творческой личности Б.Е. Захавы. В своей практике Вахтангов отошёл от реализма раннего МХТ и создал собственное направление, которое сам называл фантастический реализм. Благодаря его педагогическому таланту появилось множество замечательных актёров, которые смогли добиться независимости Студии и организовать не только театр имени своего учителя, но и сохранить театральную школу, основанную на принципах работы Евгения Богратионовича. Имя Захавы в

23 октября 1914 года Е.Б. Вахтангов прочёл первую лекцию по системе К. С. Саниславского студенческой молодёжи Московского коммерческого института. Так родилась Мансуровская студия, а в дальнейшем зародилась школа, которая настоящее время не часто можно усльшать в театральной среде, однако его вклад в сохранени Театра имени Евгения Вахтангова и Театрального института имени Б. Щукина является основополагающим. Система образования в стенах Театрального института имени Б. Щукина была создана на основе практических трудов К.С. Станиславского (1курс) и теоретическо-практических тру дов Б.Е. Захавы, сохранившего в своей памяти заветы своего учителя - Евгения Вахтангова. Работа над созданием методики по актёрскому мастерству активным образом шла в 30-е годы XX века. На протяжении целого ряда лет Захава занимался выстраиванием системы образования, привлекая непосредственных учеников Вахтангова к педагогической деятельности в училище. И в результате родилась эта стройная образовательная система с определёнными целями и задачами, а также и набором упражнений дл каждого семестра. Б.Е. Захава способствовал созданию одного из лучших театральных учебных заведений страны. Его деятельность была целиком и полностью направлена в педагогическо русло для помощи студентам в освоении Вахтановской методики воспитания.

Ключевые слова: режиссер, студия, соревнователи, постановка, профессиональный самодеятельность, реализм, семестр, мизансцена, задача.

сейчас называется Театральный институт имени Бориса Щукина. В числе первых учеников был и Б.Е. Захава, который впоследствии вспомина эту встречу: «Я ученик Станиславского, - сказал вахтангов. - Смысл своей работы у вас вижу в 
том, чтобы пропагандировать и распространять учение Константина Сергеевича» ${ }^{1}$.

После окончания курсов актёрского мастерства школы А.И. Адашева в Москве Евгения Богратионовича приняли в труппу Московского художественного театра. Там он, помимо актёрской деятельности, начал всерьёз заниматься ре жиссурой, посещал репетиции К.С. Станиславского и работал в качестве второго режиссёра с Вл.И. Немировичем-Данченко. Константин Сергеевич заметил упорство и заинтересованность начи нающего свой профессиональный путь актёра через некоторое время предложил ему заняться активной педагогической деятельностью с группой молодых актёров. Системы Станиславского ещё не существовало в опубликованном виде поэтому Вахтангову приходилось идти не от теории к практике, а наоборот, практически доказывать творческую состоятельность новых методов преподавания актёрского мастерства. В скором времени, благодаря его успешной работе по методике Станиславского, руководством театра было принято решение о создании Студии при MXT (впоследствии получившей название Первой студии) под руководством Л.А. Сулержицкого, где Вахтангов поставит «Праздник мира» (1913г.) Г. Гауптмана, «Потоп» (1915 г.) Г. Бергера, «Росмерсхольм» (1918 г.) Г. Ибсена, «Эрик XIV» (1921 г.) А. Стриндберга, а также сыграет несколько выдающихся ролей: Текльтон (1914 г.) в сказке «Сверчок на печи» Ч. Диккенса, Фрезер (1915 г.) в пьесе «Потоп» Г. Бергера.

Евгений Богратионович - один из самых вер ных сторонников метода К.С. Станиславского, целью которого является передача актёром «жизни человеческого духа роли» через естественное органичное существование в предлагаемых обстоятельствах пьесы. Важнейшей задачей систе мы является овладение артистом естественным чувством, позволяющим на сцене действовать $и$ ыслить почти так же, как в реальной жизни. Основное отличие заключается в том, что в жизни у человека срабатывает первичная эмоциональная система, являющаяся ответом на факторы, вли яющие на него извне, своеобразный инстинкт самосохранения, а в момент сценического существования у актёра происходит проявление вторичной эмоциональной системы, искусственно посредством технических элементов, воссоздава1. Захава Б.Е.: Воспоминания. Спектакли и роли. Статьи. М.
1982. С. 42.

емой им в конкретных предлагаемых обстоятельствах: «На этой основе им (К.С. Станиславским) был выработан ряд приёмов психотехники, выбывающих к творчеству внутренний мир человека»².

Б.Е. Захаве суждено было продолжить дело Вахтангова, занимаясь развитием методологи театральной педагогики и сохранением наследия великого учителя. Пройдя трёхлетнюю программу обучения в Мансуровской студии, Борис Евгеньевич проявил интерес к режиссуре и педагогике. В 1918 году Евгений Богратионович создал режиссёрские и преподавательские классь для того, чтобы его актёры могли сами заниматься постановкой спектаклей и педагогической деятельностью. Этот период существования школь важен также тем, что молодые кадры, недавно бывшие студийцами, профессионально окрепли поэтому Е.Б. Вахтангов отказался от приглашения педагогов со стороны; теперь он мог всецело положиться на знания своих артистов. Тем более практикуемый метод воспитания и обучения будущих актёров требовал единого направления основанного на принципах Вахтанговской школы, которыми в полной мере могли владеть лишь ученики Евгения Богратионовича. В режиссёрский класс вошли К.И. Котлубай, Ю.А. Завадский и Б.Е. Захава. Борис Евгеньевич, по рекомендации своего учителя, вёл педагогическую деятельность и в других коллективах. Некоторые ученики этих те атральных сообществ в дальнейшем примкнут к Вахтанговской студии

Евгений Богратионович Вахтангов много вни мания уделял эстетическому, нравственному вос питанию своих учеников. В коллективе приняли свод правил и законов, выполнение которых было обязательно для всех членов театральной организации: «Студийцы столько внимания отдают моральному кодексу студии, что он начинае становиться для них самоцелью» ${ }^{3}$. Для него процесс внутреннего развития являлся основополагающим, помогал выявлению мировоззренческих взглядов у художника, а также возможность чутко ощущать современность и выражать её чере личностное отношение в своём творчестве. Пе дагогический талант Вахтангова прежде всего заключался в том, что к каждому студийцу у него

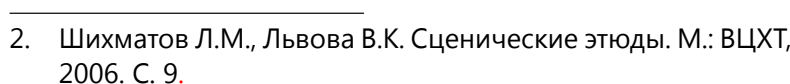
3. Херсонский Х.Н. Вахтангов. (Жизнь замечательных людей) существовал индивидуальный подход. Он с лёгкостью мог увлечь ученика творческой атмосферой на репетиции и пробудить в нём желание к самостоятельной внутренней работе над ролью. В школе создавали условия, при которых будущие актёры могли и хотели заниматься постижением профессии. Евгений Богратионович считал, что при таком подходе у начинающих постигать азы мастерства происходит осознание необходимости собственного развития. Ученики чувствуют, что они могут пробовать, ошибаться, заниматься процессом познания своей индивидуальности, ощущают внутреннюю свободу, что даёт возможность профессионального роста.

Методика преподавания актёрского мастерства создавалась и корректировалась не одно десятилетие. В этом основную роль сыграл Б.Е. Захава. Постепенно, с 1931 по 1941 год, сформировалась система обучения. В 1925 году Б.Е. Захава ввёл в программу школы, при театре Евг. Вахтангова, кафедральный принцип работы с учениками. В письме к О.Ф. Глазунову он говорит о необходимости создания нового подхода к воспитанию учащихся: «Необходимо каждого воспитанника поставить, так сказать, под перекрёстный огон различных педагогических воздействий, преподавательских индивидуальностей» ${ }^{4}$. С этого времени начинается активная работа по созданию основных принципов обучения. Творческий процесс с максимальным количеством педагогов имеет значение с точки зрения расширения потенциала студента, с другой стороны, если с одним преподавателем «химического» (творческого) процесса не произошло, то с другим рабочий процесс может получиться более успешным. Эта идея Б.Е. Захавы в дальнейшем поможет выпускникам взаимодействовать с разными режиссёрами, сделает актеров более гибкими в подходе к профессии.

Б.Е. Захава из тех руководителей, которые придавали большое значение так называемым специальным дисциплинам. Например, если студент пропускал вспомогательный предмет, то он не допускался до занятия мастерством актёра, что было для студента неимоверно тяжёлым наказанием. В 1936 году проходит реорганизация техникума с 3-годичным обучением - в училище с 4-годичным. Данная реформа дала положительные результаты в связи с введением дополнительного ряда искусствоведческих предметов,

4. Вахтанговская школа. Летопись. Ч. 1. Из личного архива
Б.Е. Захавы. М.: Т.И. им. Б. Щукина, 2004. С. 81-82.

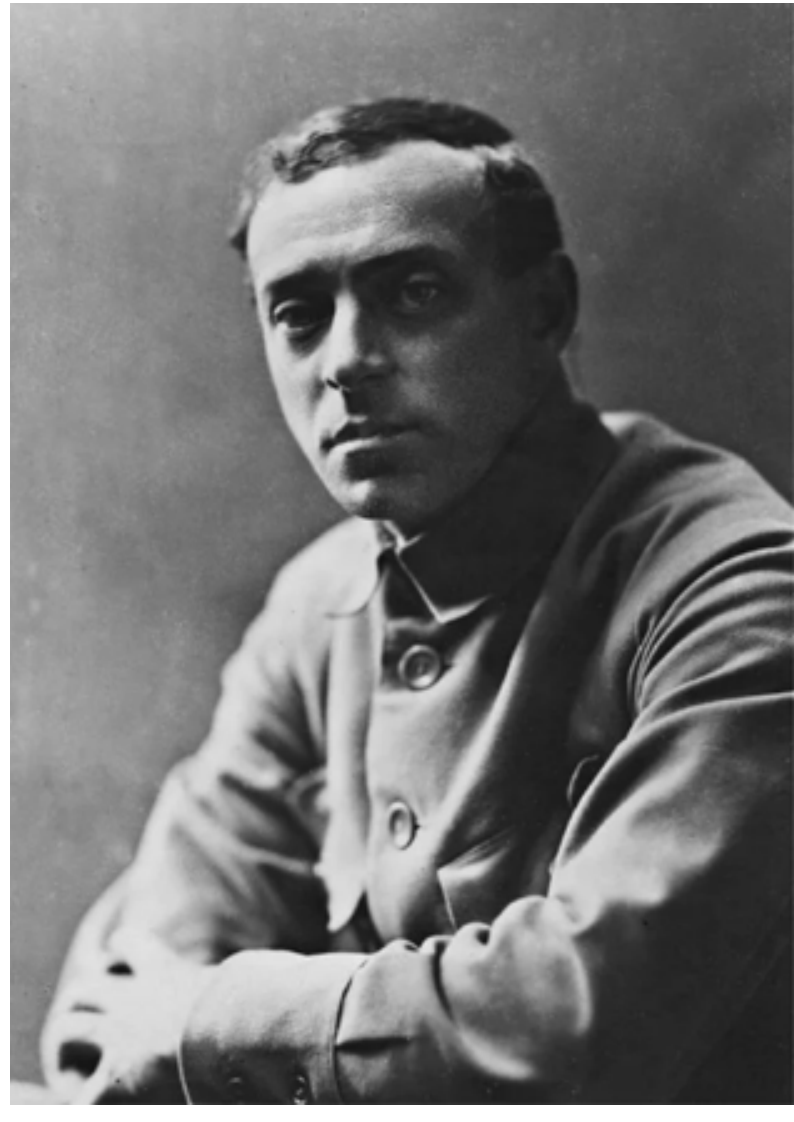

Е.Б. Вахтангов

повысивших общекультурный уровень учащихся: «Мастерство - это всё, из чего состоит наш учебный план. Вся сумма знаний и умений, которые должен приобрести студент нашего учили ща, - это и есть мастерство». ${ }^{5}$ Педагоги искали верный подход к ученикам, стараясь объяснить необходимость всестороннего развития. Конеч но, в начале они сталкивались С непонимани ем со стороны студентов. Однако, со временем ученики почувствовали пользу от такого подхода к обучению.

Подробно в 30-е годы XX века была разработана и новая программа по мастерству актёра. Все определения и формулировки были уточнены, некоторые разделы доработаны и расширены: "Стали проводиться методические эксперименты. Найденное - закреплялось в программе. Словом, происходила серьёзная научно-методическая работа»6. Примерно с 1935 года Б.Е. Захава принял решение о внедрении и проверке некоторых

5. О формировании личности студента в театральном ВУзе. Статья. 1971-1974 гг. Российский государственный архив литературы и искусства. Ф. № 3034, опись № 1, ед. хр
№ 152 . С 34 .

6. Захава Б.Е. Театральное училище им Б.В. Щукина при театре
имени Евг. Вахтангова: Рукопись. Архив Т.И. им. Б. Щукина, 1951. - C. 22 
основ методики, а уже к 1939 году ввёл новую образовательную систему преподавания актёрского мастерства для учащихся. Этот шаг является основополагающим в процессе дальнейшего становления училища как одного из лучших учебных заведений страны. Конечно, введённая программа прежде всего повлияла на подготовку выпускников и их актёрский арсенал. Педагогами училища и режиссёрами театра имени Евг. Вахтангова акцентировалось внимание на различии между выпускниками школы до введения новой методики и после: «Начиная примерно с 1938 года в труппу Вахтанговского театра стали посту пать наши выпускники, с которыми просто работать. Они умеют работать самостоятельно они знают, как взяться за роль»'. Выпускники училища, до введения новой системы обучения по воспоминаниям педагогов, конечно, были талантливыми артистами, однако, зачастую, в своей профессии им приходилось достаточно сложно во взаимодействии с режиссёрским подходом в интерпретации того или иного художественного произведения, особенно, если им предлагалось самостоятельно проработать материал роли.

Вплоть до середины 30-х годов XX века школа, под руководством Захавы, находилась в стенах театра имени Евг. Вахтангова, что позволяло учащимся, будучи на 1-м курсе, принимать участие в профессиональных постановках. Однако, с внедрением четырёхлетнего образования 1936 году и изменением методики преподавания, к 1937 году училище, отделившись от театра, обзавелось новым зданием, поэтому появилась возможность внедрить в систему обучения важнейший практический инструмент - Учебный театр, введённый в эксплуатацию параллельно с училищем по адресу Большой Николопесковский переулок, д. 12а. Появление нового поме щения, а с ним и дополнительных возможностей для творческого развития, позволило с 1939 года теперь уже училищу имени Б. Щукина, названному в честь лучшего актёра театра Евг. Вахтангова, ушедшего из жизни в том же году, ставить на постоянной основе дипломные спектакли, завершающие процесс обучения. Ученики получили возможность познакомиться с невероятно инте-

7. Стенограмма занятия творческой лаборатории режиссёро народных театров. Беседа С Б.Е. Захавой (о воспитании № 970, опись № 21, ед. хр. № 3193 . С. 35 . ресным и сложным устройством театра, так как обслуживанием дипломных спектаклей занимались первокурсники, получая тем самым неоцелись первокурсник, получая тем сауым неоц театра, обучаясь определённым законам поведения и взаимоотношения с рабочими, костюмерами, художниками. В дальнейшем полученны ими знания помогали безболезненно перейти коллектив любого профессионального театра, так как выпускники внутренне уже были готов к специфике отношений в таком сложном организме. Борис Евгеньевич считал такую практику залогом успешного освоения театральной профессии: «Без практики ученических спектаклей, без наличия постоянно функционирующе го учебного театра никакая икола не сможет осуществить эту воспитательную задачу». Уже после окончания Второй мировой войны в 1945 году училище наделили правами высше го учебного заведения, в связи с чем стало возможным направлять выпускников для работы во многие театры страны.

В 1951 году состоялась встреча педагогов те атрального института имени Б. Щукина во главе с Б.Е. Захавой с комиссией из ГИТИСа под руководством заведующего кафедрой актёрского мастерства профессора И.М. Раевского. Проводились консультации по вопросам методик обучения актёрскому мастерству. Особое внимание уделялос процессу обучения студентов на втором курсе: профессиональний навык, наблюдения и упражнения на элемент сценического образа. Представителями из ГИТИСа было предложено изучат суть сценического перевоплощения на основ идейного смысла литературного произведения, а не придумывать предлагаемые обстоятельства, как это делали до этой встречи: «Они были правы в этом (говоря об оценке со стороны комиссии из ГИТИСа). Поэтому мы перестроили свою ра боту, мы внесли существенную реформу, мы пе рестали называть эти упражнения на элемент сценического образа, а стали называть - упражнения к образу благодаря заданию из того или иного литературного материала»9. Эта встре ча и сторонний взгляд преподавательского состава ГИТИСа оказали существенное влияние на изменение раздела программы обучения первоимени Евг. Вахтангова: Рукопись. Архив Т.И. им. Б. Щукина, 9. Там ж.. C. 26 го семестра 2-го курса. В итоге этот раздел принял окончательный и завершённый вид.

Возвращаясь к конкретной структуре методических основ программы обучения студентов в Театральном институте имени Б. Щукина, мь видим, что, безусловно, с учётом времени данная методика преподавания в некоторых аспектах претерпела изменения, но суть, заложенная Б. Вахтанговым, сформулированная, а также дополненная и последовательно структурированная Б.Е. Захавой, остается основой и не меняется.

Первый год обучения отдан прохождению разделов системы Станиславского, базирующихся на принципе жизненной правды, учении о сверхзадаче, действии как основы актёрской техники органичности и творческого перевоплощения актёра в образ. Главная задача системы Константина Сергеевича заключается в выявлении у артиста органичного самочувствия и естественного процесса перевоплощения. В течение всего первого года учащиеся усваивают теоретически и закрепляют посредством практики сценическую азбуку, то есть основные законы внутренней тех ники актёрского искусства. Происходит процесс воспитания в студентах определённых способностей и навыков, которые впоследствии помогают ученику подойти к верному сценическому самочувствию, то есть к конкретным и правди вым условиям творческого акта. Соответственно, на 1-м курсе главная цель заключается в выявлении у учащихся «чувства правды», то есть органичного существования на сцене. Весь первый год они существуют в рамках «я в предлагаемых обстоятельствах». Как это ни парадоксально может звучать, но на первом этапе овладевания элементами сценического существования, как говорил Борис Евгеньевич: «Мы забываем всё: и то, как в жизни ходим, и то, как мы сидим, едим, пьём, спим, разговариваем, смотрим $»^{10}$. Этот этап очень важен для будущего актёра, так как создание образа происходит через подключение личностного чувственного ряда, сопоставимого с эмоциональной природой персонажа, которого играет актёр в спектакле. Однако это ещё не является самим сценическим образом, это лишь ос нова, на которой строится роль. На первом этапе взаимоотношений сучениками важна последовательность изучения на практике элементов верного сценического самочувствия, впоследствии 10. Шихматов Л.М, Львова В.К. Сценические этюды. М.: ВцХТ, 2006. C. 24. подводящих к органическому зарождению действия в сценическом существовании студентов. Существует ряд упражнений, которые выполняют ученики: на внимание, физическую свободу, выполнение простых физических действий на фантазию и воображение, перемену отношения к предмету, месту действия, а также упражнения на физическое самочувствие и на память физических действий, упражнения на оценку факта, событие, перемену отношения к партнёру, на сценическое общение и этюды на общение в условиях органического молчания, сценические отношения в рамках магического «если бы»; важное уточнение, что все упражнения выполняют ся без слов. Следующей ступенью в программе 1-го курса являются простейшие сюжетные этюды в условиях оправданного молчания (без слов). Прохождение этого элемента обучения подводит студентов к органическому рождению слова. Конечно, в этих этюдах допускается небольшое количество оправданного текста, выражающего событийное изменение или эмоциональное выявление ученика в конкретный момент поворота сюжетной линии.

Как правило, параллельно с этюдами на оправданное молчание, студенты проходят раздел, который называется память физических действий. Благодаря этим упражнениям происходит проверка наработанных ранее навыков: внимания внутренней мышечной свободы, сценической веры, физических ощущений. Этот раздел, конеч но, помогает в дальнейшем учащимся затрачи вать ровно столько физических усилий, сколько необходимо для правильного взаимодействия настоящими предметами в условиях сценического действия. Процесс работы над упражнениями на память физических действий достаточно сложен и требует максимального вовлечения студента, которому необходимо добиться высочайшего исполнения.

На втором семестре первого года обучения студенты проходят обучение логичному и целесообразному действию на сцене в заданных предлагаемых обстоятельствах в этюдах с импровизированным текстом. За время участия в таких упражнениях ученики учатся понимать суть физических и словесных действий, а также разбираются в неделимости физического и психи ческого в природе актёрского существования. В конце года студенты сдают этюды с импровизированным текстом, сюжетная линия которых по- 
зволяет учащимся оставаться самими собой и действовать в условиях «я в предлагаемых обстоятельствах». На протяжении всего первого курса существует строгая последовательность прохождения элементов системы К.С. Станиславского.

Второй курс (в условиях трехгодичной системы обучения - третий курс) Е.Б. Вахтангов любил называть: «Наш курс» ${ }^{11}$. Программа первого семестра этого курса принципиально отличается от других театральных школ. Поиск пути к созданию образа является отдельным разделом обучения. Включает в себя: наблюдения, профессиональный навык и этюды к образу. Б.Е. Захава часто повторял фразу, которая стала знаковой для института: «Стать другим, оставаясь самим собой» ${ }^{12}$. Именно этот принцип органического перевоплощения положен в основу этого полугодия. Наблюдения являются первым серьёзным шагом к сценическому образу. В этот семестр студенты сталкиваются с необходимостью наблюдать за окружающей жизнью, запоминать повстречавшихся им интересных людей с необычными чертами характера, подмеченные детали в поведении учащиеся собирают в свою актёрскую «копилку». Наблюдают ученики не только за людьми но и за животными и даже предметами, наделяя их человеческим характером. Удачным считается то наблюдение, в котором студент сумел выразить «зерно», то есть суть другого человека, присвоенную актёром, которая на время стала для него собственной и родной. В показ входят наблюдения за человеком, животными, упражнения на фантазию - наблюдения за предметами, а также музыкальные наблюдения за известными артистами эстрады. В этом же семестре учащиеся осваивают профессиональный навык (физи ческая деятельность конкретной профессии). Ни в коем случае студент не должен действительно овладеть той или иной профессией, важно уловить её внешнюю характерность. Так как ученик впервые сталкивается с тем, что сценическое время существенно отличается от жизненного, то и цель этого задания - точечная и конкретная ими тация профессионального процесса, заключающаяся в свободных и конкретных движениях. В течение всего третьего семестра на втором курсе учащиеся последовательно занимаются поис

11. Захава Б.Е. Театральное училище им Б.В. Щукина при театре имени Евг. Вахтангова: Рукопись. Архив Т.И. им. Б. Щукина, 12. Taм ж. C. 30 раза на основе литературного материала. Материал лучше всего подбирать такой, в котором автор произведения не предъявлял особых требований к форме и предлагеммне обстоятельства понятны или хорошо знакомы студентам. Важной педагогической задачей является точное распределение ролей между учащимися, так, на этом этапе важно подобрать для каждого студента близкий именно его индивидуальности материал. Студенты в процессе работы над созданием образа пробуют присвоить отношения другого человека (персонажа). Главная задача - проверить насколько были усвоены основные разделы театральной школы и знакомство с методом работы над ролью в условиях конкретной драматургии.

На третьем курсе обучения ученики играют многосоставные отрывки, из произведений мировой драматургии. Сценическое время существования студентов в первом семестре увеличивается до 15-20 минут, а уже во втором семестре третьего курса предлагается целый акт как заявка на спектакль.

На четвёртом курсе учащиеся в течение целого года обучения играют дипломные спектакли. Художественный руководитель составляет репертуар курса, распределяя роли между учащимися с тем, чтобы практически каждый был занят не менее чем в двух постановках. Б.Е. Захава придавал огромное значение репертуару театра учили ща и предлагал педагогам заниматься этим уже с 1-го курса.

Ещё одной отличительной чертой Вахтанговской школы является наличие в институте показов самостоятельных работ студентов. Ученики начиная со второго семестра 1-го курса готовят свои показы. Они выбирают близкий им материал и без посторонней помощи над ним работают, а затем играют отрывки педагогам кафедры. Работа студентов первого курса не должна идти больше 10-13 минут и нежелательно сразу брать шедевры мировой драматургии. На втором курсе материал уже выбирается посложнее, а на третьем году обучения учащимся предлагается возможность провести два таких показа. Необходимо также отметить, наличие на третьем курсе еще и исполнительских вечеров, на которых може присутствовать посторонний зритель. Эти про раммы, как правило, составляются из лучших педагогических отрывков четвёртого и экзаменационных работ пятого семестров. Самостоятельные показы и исполнительские вечера входя в методику профессионального обучения и неслучайно были введены в учебный процесс Б.Е. Захавой. Е.Б. Вахтангов, занимаясь со студийцами, внедрил в обязательную программу показь ученических работ и открытых исполнительских вечеров. Борис Евгеньевич прекрасно понимал пользу такого педагогического подхода в работе с учениками, потому что такие пробы творчества помогают студенту неожиданно раскрыться, продемонстрировать педагогам свой внутренний мир, жизненные взгляды, ведь сцена - своеобраз ное зеркало, где можно отчётливо увидеть инди видуальные особенности учащегося.

Борис Евгеньевич Захава - один из немногих, кто пришел в Студию в год её основания и остался предан ей на всю жизнь. Он внёс огромный вклад в становление Театрального института имени Б. Щукина и сохранение театра имени Евгения Вахтангова. Более 50 лет он был ректором института, за этот период была окончательно оформлена программа воспитания и обучения актёрскому мастерству, благодаря чему выпущено огромное количество величайших актёров, а также основан Режиссёрский факультет. Пройдет не одно десятилетие и Б.Е. Захава определит для себя, каким должен быть идеальный выпускник театрального училища имени Б. Щукина: «Однажды я задумался над вопросом, каким мне хотелось бы видеть каждого воспитанни ка нашего Щукинского училища. Мне захотелось сконструировать в своём сознании, если можно так выразиться, идеальную модель выпускника театрального вуза. Я насчитал примерно шесть основных граней такой модели: талант и блестящую технику, способность глубоко и со держательно мыслить, проникая в самую суть жизненных явлений, высокие нравственные ка чества, общественную активность» ${ }^{17}$.

К семестр связан с изучением процесса создания об 13. Захава Б.Е. Театральное училище им Б.В. Щукина при театре имени Евг. Вахт
1951. С. $40-41$.

14. Буров А.Г., Любимцев П.Е. Мастерство актера. М. Театральный институт имени Бориса Щукина, 2005. С. 22 Захава Б.Е. Театральное училище им Б.В. Щукина при театр имени Евг. Вахтангова: Рукопись. Архив Т.И. им. Б. Щукина, 16. Там ж. С. 30 


\section{БИБЛИОГРАФИЯ}

1. Буров А.Г., Любимцев П.Е. Мастерство актёра. - М.: Театральный институт имени Бориса Щукина, 2005. - 36 с.

2. Вахтанговская школа. Летопись. Ч. 1.: Из личного архива Б.Е. Захавы. - М.: Т.И. им. Б. Щукина, 2004. - 376 с.

3. Захава, Б.Е.: Театральное училище им Б.В. Щукина при театре имени Евг. Вахтангова: Рукопись. - Архив Т.И. им. Б. Щукина, 1951. - 64 с.

4. Захава Б.Е. Праздник человеческого духа // Октябрь. - 1961. - № 9. -16 c.

5. Захава Б.Е. Воспитание режиссёров в Щукинском училище // Театр. - 1975. - № 7-8. - 115 с.

6. Захава Б.Е. Воспоминания. Спектакли и роли: Статьи. - М., 1982. - 402 с.

7. Захава Б.Е. Об обучении в театральном училище имени Б. В. Щукина. - Ф. № 034, опись № 1, ед. хр. 188, начало 1970-х. - 12 с.

8. Херсонский Х.Н. Вахтангов. (Жизнь замечательных людей). - М.: Молодая гвардия, 1940. - 318 с.

9. Шихматов Л.М., Львова В.К. Сценические этюды. М.: ВЦХТ, 2006. - 240 с.

10. О формировании личности студента в театральном ВУЗе: Статья. 1971-1974 гг. - Российский госу- дарственный архив литературы и искусства. - Ф. № 3034, опись № 1, ед. хр. № 152. - 34 с.

11. Стенограмма занятия творческой лаборатории режиссёров народных театров. Беседа с Б.Е. Захавой (о воспитании актеров) 8 октября 1961 года на 67 листах. - Центральный государственный архив литературы и искусства СССР. - Ф. № 970, опись № 21, ед. хр. № 3193. - 35 с.

12. Wollen W. 2016. «The active text: unlocking plays through physical theatre», Stanislavski Studies, no. 4, pp. 83. DOI:10.1080/20567790.2016.1155370( in English).

13. Skinner A. 2015. "An Introduction to the Russian Theatre Research Network», Stanislavsky Studies, no. 3, pp. 32. DOI:10.1080/20567790.11428609 (in English).

14. Shulgat A. 2016. "Vsevolod Meyerhold: actor as the texture of theatre», Stanislavski Studies, no. 4, pp. 179. DOI: 10.1080/20567790.2016.1241553 (in Russian).

15. Aquillina S. 2020. «Teaching Stanislavsky: periodization and the formation of theatre canons», Stanislavski Studies, no. 2, pp. 53. DOI: 10.1080/20567790.2020.1718862 (in English). 